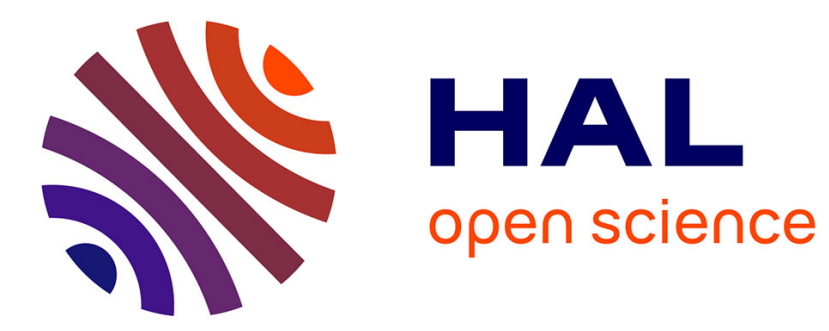

\title{
From molecules to societies: mechanisms regulating swarming behavior in honey bees (Apis spp.)
}

Christina Grozinger, Jessica Richards, Heather Mattila

\section{To cite this version:}

Christina Grozinger, Jessica Richards, Heather Mattila. From molecules to societies: mechanisms regulating swarming behavior in honey bees (Apis spp.). Apidologie, 2014, 45 (3), pp.327-346. 10.1007/s13592-013-0253-2 . hal-01234732

\section{HAL Id: hal-01234732 \\ https://hal.science/hal-01234732}

Submitted on 27 Nov 2015

HAL is a multi-disciplinary open access archive for the deposit and dissemination of scientific research documents, whether they are published or not. The documents may come from teaching and research institutions in France or abroad, or from public or private research centers.
L'archive ouverte pluridisciplinaire HAL, est destinée au dépôt et à la diffusion de documents scientifiques de niveau recherche, publiés ou non, émanant des établissements d'enseignement et de recherche français ou étrangers, des laboratoires publics ou privés. 


\title{
From molecules to societies: mechanisms regulating swarming behavior in honey bees (Apis spp.)
}

\author{
Christina M. Grozinger ${ }^{1}$, Jessica Richards ${ }^{1}$, Heather R. Mattila ${ }^{2}$ \\ ${ }^{1}$ Department of Entomology, Center for Pollinator Research, The Pennsylvania State University, 4A Chemical \\ Ecology Lab, Orchard Road, University Park, PA 16802, USA \\ ${ }^{2}$ Department of Biological Sciences, Wellesley College, 106 Central Street, Wellesley, MA 02481, USA
}

Received 16 July 2013 - Revised 18 October 2013 - Accepted 25 October 2013

\begin{abstract}
Reproduction by colony fission, or swarming, is a spectacular example of a behavior that requires the simultaneous coordination of the activities of thousands of honey bee workers and their queen. The successful execution of this collective phenomenon relies on the appropriate response of individuals in swarms to a myriad of signals that are produced by workers and queens to synchronize their nest exodus, subsequent house hunting, and eventual relocation to a new nest site. In this review, we describe our current understanding of the social factors that trigger swarming in colonies and the nonchemical and chemical signals that mediate a coordinated transition between its stages. We also highlight emerging work on the physiological and genomic mechanisms underpinning swarming behavior. Finally, we discuss the possible evolutionary origins of swarming behavior, through comparisons with related behaviors of migration, overwintering, estivation, and diapause in honey bees and other insects.
\end{abstract}

\section{collective behavior / swarming / chemical communication / physiology / genomics / honey bee}

\section{INTRODUCTION}

Elucidating the proximate and ultimate mechanisms that regulate social behavior is one of the great challenges in biology. With the development of new genomic tools and resources, it is becoming increasingly feasible to examine these questions in a wide array of species in their natural habitats and to perform sophisticated comparative studies that examine the molecular mechanisms by which social behavior evolved from solitary behaviors (reviewed in Toth and Robinson 2007; Robinson et al. 2008). However, the majority of social behaviors that have been studied have

Corresponding author: C. M. Grozinger, cmgrozinger@psu.edu

Manuscript editor: Stan Schneider involved interactions between a small number of individuals (i.e., courtship, mating, and aggression; Clayton 2004; Villella and Hall 2008; Anholt and Mackay 2012; Cummings 2012) or, in the case of social insects, differences between individuals who specialize in different tasks within a group (e.g., division of labor, Smith et al. 2008). The molecular mechanisms that regulate collective behaviors, in which the majority of individuals in a group perform a coordinated behavior, have not been comprehensively examined outside of aggregations of single-celled organisms such as bacteria, yeast, and social amoeba (Velicer and Yu 2003; Queller 2008; Li and Purugganan 2011), with the exception of gregarious behavior in migrating locusts (Ma et al. 2011; Ott et al. 2012). Examples of such collective behaviors include schooling in fish, migration in birds or locusts, and synchronized applause in human audiences (Sumpter 2006), where a group 
of individuals, regardless of their individual states or preferences, simultaneously perform similar behaviors such that the group behaves cohesively.

In a honey bee colony, there are several colony-level phenomena in which the behavior of a queen and tens of thousands of her worker daughters must be coordinated to sustain their colony's survival and function. In established colonies, one of these phenomena is reproductive division of labor, where queens lay eggs that are tended to adulthood by facultatively sterile workers, who typically lay eggs only in the absence of a queen and brood (Wilson 1971). Workers also exhibit age-based division of labor, where they specialize on different tasks as they mature, with young "nurse" bees performing brood care and older "forager" bees collecting resources from the environment (Robinson 1992; Seeley 1995). Foraging itself is another essential colony-level process where the activities of a substantial portion of the population are finely coordinated to facilitate efficient discovery and exploitation of profitable food sources (reviewed in Seeley 1995). A final and remarkable example is that of reproductive swarming (hereafter referred to simply as "swarming"), a process of colony fission in which a colony's queen and approximately twothirds to three-quarters of its workers leave their original (or parental) nest to find a new colony (Martin 1963; Getz et al. 1982; Rangel and Seeley 2012). Upon leaving, a swarm's workers form a temporary cluster (called a bivouac) and initiate a search for a new nest site while they are homeless. The workers who remain behind raise one of the queen's daughters as their new queen (reviewed in Winston 1987; Seeley 2010).

Previous studies have examined the molecular mechanisms that regulate reproductive division or labor, worker division of labor, and foraging in honey bees (Whitfield et al. 2006b; Grozinger et al. 2007a; Page et al. 2012), and the information gained from these studies has laid the groundwork to examine how these complex social behaviors evolved from behaviors observed in solitary species (i.e., BenShahar et al. 2002). However, the molecular mechanisms regulating swarming behavior have only recently been considered (Liang et al. 2012; Richards et al. unpublished data). Swarming requires communication and coordination on a grand scale, making it an excellent model system in which to examine the social and molecular mechanisms that organize this collective behavior in an effort to understand how such complex processes could evolve. While there has been considerable interest in elucidating the behavioral and chemical signals that coordinate swarming, how these are translated at the genomic and physiological level into changes in behavior remain largely uncharacterized. Here, we will review the factors that stimulate a colony to prepare to swarm, the nonchemical and chemical signals that coordinate the swarm's departure and movement to a new nest site, and the genomic and physiological pathways that are associated with a worker's decision to depart with the swarm or remain in the colony. We will also explore the possible evolutionary origins of swarming behavior in honey bees, comparing and contrasting swarming with diapause in solitary insects, overwintering and estivation in honey bees and migration in tropical honey bees, and highlight research questions that may provide insights into the evolution of this fascinating behavior.

\section{OVER V I E W O F S WA R M PREPARATION AND SWARMING IN HONEY BEE COLONIES}

Swarming is a complex, multi-step process that is mediated by multiple environmental, social, physiological, and molecular factors (see Figure 1). Swarming typically occurs during specific times of the year, usually when resources are plentiful to support rapid population growth (Simpson 1959). This population growth underpins four colony-level changes that have been hypothesized to trigger swarming preparation: increasing colony size (in terms of both number of workers and amount of comb), congestion of the brood nest, skewing of worker age distribution toward younger individuals, 


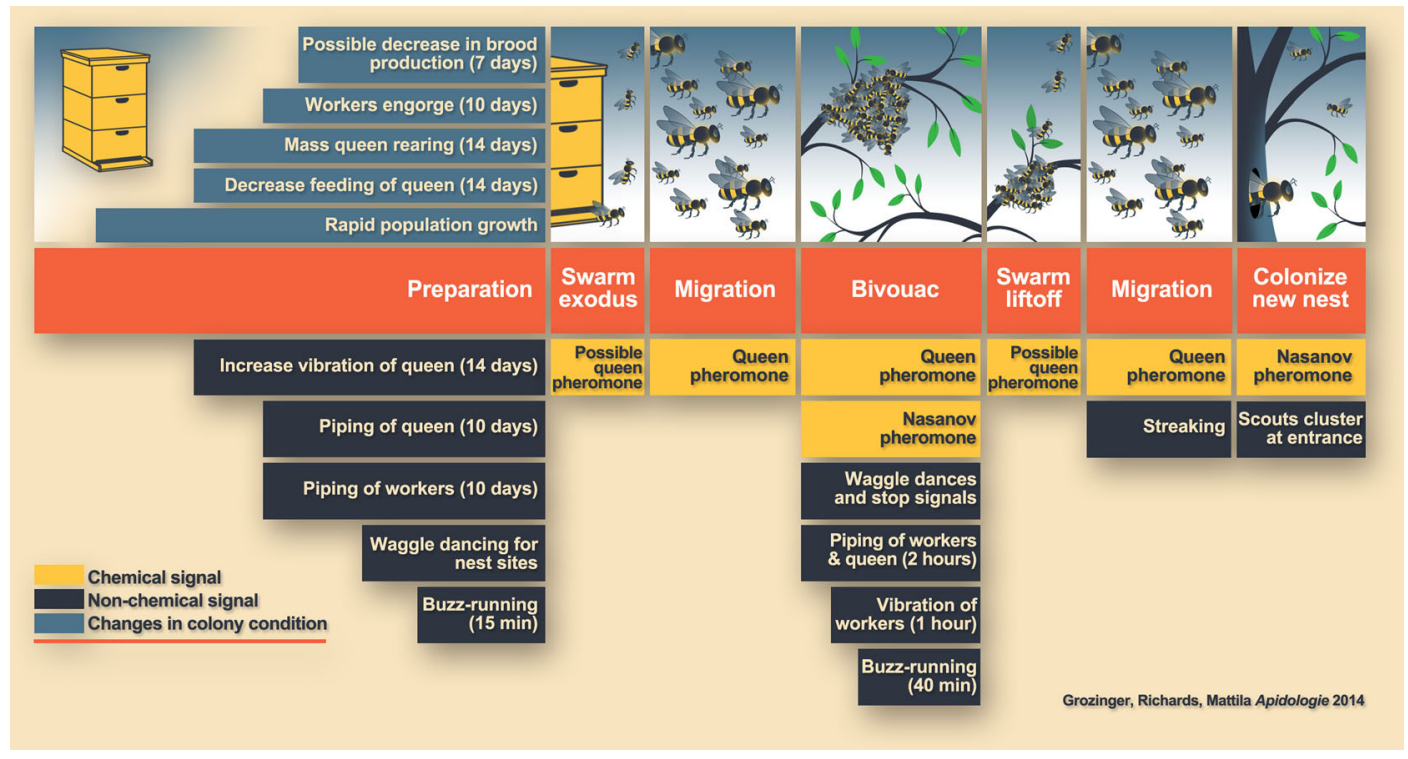

Figure 1. Overview of swarming in honey bees, A. mellifera. Reproductive swarming in honey bees occurs via a series of distinct phases (shown in orange and depicted graphically). The activities of colony members during these phases and their transitions are coordinated by nonchemical (highlighted in black) and chemical signals (highlighted in yellow) from queens and workers. In cases where signals coordinate swarm movement (i.e., exodus or liftoff), we note the period of time prior to movement during which the signals are produced. We hypothesize that volatile queen pheromones are involved in swarm exodus and liftoff (designated as "possible queen pheromone"), but further studies are necessary to confirm this. Finally, note that "rapid population growth" prior to swarming leads to other colony conditions that may trigger swarm preparation, including increased colony size and congestion, congestion of the brood nest, and decreased concentration and/or transmission of queen pheromone (see text for further details). This figure was developed with assistance from Nick Sloff (Pennsylvania State University); line drawing of hive by Jonathan Snow (Barnard College).

and reduced transmission of queen-produced substances/pheromone (reviewed in Winston 1980, 1987; Simpson 1958). However, these factors likely act in concert or are correlated with an as-yet-unidentified critical cue because individually they do not reliably trigger swarming. Honey bees swarm as populations rapidly increase in size, with a colony reaching 20,000 bees issuing a swarm of $\sim 16,000$ bees on average (Winston 1979; Winston et al. 1981). Colonies in which worker densities are higher than 2.3 workers $/ \mathrm{mL}$ initiate queen cell building (the first clear sign of swarm preparation, see below) and, above this threshold, colony density is positively correlated with the number of queen cells that workers construct
(Lensky and Slabezki 1981). Colonies also initiate rearing of new queens when more than $90 \%$ of their brood comb is in use (Winston et al. 1981), suggesting comb congestion and queen rearing are also closely correlated. However, while congested colonies generally swarm earlier than uncongested colonies (Simpson 1957b; Winston et al. 1991), not all congested colonies swarm (Simpson 1957a) and colonies that are relatively uncongested can still swarm readily (Simpson 1957b). Furthermore, adding or removing eggs and young larvae to shift the worker-brood ratio, thereby manipulating congestion in the brood nest, does not trigger swarming (Simpson 1957a). A skewed worker age distribution is also associated with swarming: colonies preparing to swarm 
tend to have a large proportion of young bees (Winston and Taylor 1980) and departing swarms are predominantly made up of younger bees (Butler 1940; Winston et al. 1981; Gilley 1998). Interestingly, in colonies preparing to swarm, adult workers appear to crowd together in the brood area, even if additional space is available in the nest (Simpson 1958; Winston and Taylor 1980). This phenomenon is likely caused by the emergence of large quantities of young workers from brood cells (Gary 1962). However, adding a large amount of young workers to colonies does not reliably trigger swarming (Simpson 1957a). Modeling studies using each individual parameter demonstrated that all three factors (colony/population size, brood nest congestion, and skewed worker age distribution) generated swarming patterns consistent with those reported empirically, but interestingly, each model only resulted in swarming when all the other variables reached thresholds defined by their individual models; thus, the parameters are highly correlated (Fefferman and Starks 2006). The authors suggested that all of these factors serve as cues for workers to determine when their colony has reached a point of "replacement stability" - meaning the worker population could care for a larger amount of brood than the queen can produce - thus the only way to increase the colony's reproductive output (and optimize fitness potential) is to produce a second queen and colony via swarming.

It is likely that honey bees use pheromones to determine whether their colony is large, congested, or has a skewed worker age distribution (Fefferman and Starks 2006). Honey bee queens produce a suite of chemical signals that serve to inform colony members of a queen's presence and quality, and these signals have significant impacts on worker behavior and physiology (Kocher and Grozinger 2011; Grozinger in press). Queenderived chemicals are transferred throughout the colony by direct contact of workers with queens (Seeley 1979) or wax (Lensky and Slabezki 1981), though there is evidence that queens also produce volatile chemicals that may circulate in colony airspace (Gilley et al. 2006; Richards et al. unpublished data). It is hypothesized that reduced concentrations of these queen-produced phero- mones in the periphery of the nest triggers the initiation of queen rearing (see below for a more detailed discussion of the chemical signals that coordinate swarming).

The initiation of mass queen rearing is the first visible step in a colony's preparation for swarming, beginning weeks before a swarm leaves the nest. While colonies can produce queen cups (specially shaped, downward-facing cells for rearing queens) throughout the summer months, these are often torn down or left empty (Simpson 1959). However, when a colony is preparing to swarm, workers construct enough cups to rear multiple (10-20) new queens, and a swarm is typically not cast from a colony until after the developing queens are sealed into these cells to initiate pupation (Allen 1956). Approximately 10-14 days prior to swarming, workers significantly reduce the amount of food they provide the queen (Allen 1955, 1956). Swarming queens thus weigh significantly less than nonswarming queens (Seeley and Fell 1981), which presumably enables them to fly long distances with a departing swarm. Despite a reduction in nourishment, queens will continue to lay eggs at an approximately pre-swarm rate until 5-7 days before swarming, when egg production precipitously declines (Allen 1955, 1956), although consistent rates of egg laying have been observed up to the time of swarming (Pierce et al. 2007). Within the same timeframe ( $\sim 10$ days before swarming), workers begin to engorge themselves on honey, which will serve as their primary source of food when they search for and establish a new nest site (Combs 1972). The quantity and concentration of food stores in the honey stomachs of workers in colonies preparing to swarm are significantly higher than those of nonswarming colonies (35 versus $10 \mathrm{mg}$ /worker; 67 versus $39 \%$ sugar by weight; Combs 1972). However, there is no difference in the contents of a worker's honey stomach between bees that join the swarm versus those that remain in the nest (Combs 1972); thus engorgement does not appear to play a role in this division of labor.

While preparation for swarming can take weeks, the swarming process itself can be over in a matter of days (reviewed in Winston 1987 
and Seeley 2010; see Figure 1 and below for more details). On the day that a swarm departs its parental nest, nonchemical and chemical signals coordinate the activity of swarming workers as they relocate to a temporary site and form a bivouac. Scout bees then search for a new nest site and communicate possible locations to other scouts (see below for more details). Once a quorum is reached, additional nonchemical and chemical signals coordinate the break up and liftoff of the bivouac and relocation to the new nest site. At the new site, workers initiate comb building and foraging and the queen resumes egg laying. Back in the parental nest, the new queen(s) emerge. The first emerging queen may leave in a swarm (called an afterswarm) or kill off the other developing or emerging queens and take over the colony. This queen will subsequently mate and initiate egg laying. Below, we will discuss the nonchemical (physical, visual, and auditory) and chemical signals that coordinate these different stages of the swarming process, and our growing knowledge of their underlying molecular and physiological processes.

\section{NONCHEMICAL SIGNALS THAT COORDINATE SWARM MOVEMENT}

When workers and their queen are finally are ready to leave the parental nest to swarm, their exodus is sudden, frenzied, and over within a matter of minutes. To ensure that all swarming bees take to the air together, multiple forms of physical, visual, and auditory communication are used to coordinate the timing of their departure. One important modulatory signal for swarming is the "vibration" or "shaking" signal, where a worker rapidly moves her body dorsoventrally, typically for 1-2 s (Gahl 1975; Visscher et al. 1999) while holding on to a receiving bee with her forelegs (reviewed in Seeley et al. 1998; Schneider and Lewis 2004). Used in multiple contexts, the message that is conveyed by this vibratory signal has been interpreted as one of "reassess your current activity" (Biesmeijer 2003), "reallocate labor to different activities" (Nieh 1998), "prepare for greater activity" (Seeley et al. 1998), or "increase your activity" (Schneider and Lewis 2004), and it is associated with a nonspecific increase in movement of recipient worker bees in the nest (Schneider et al. 1986; Nieh 1998; Cao et al. 2007), an increase in task performance (Schneider 1987; Schneider and McNally 1991; Cao et al. 2009), and a general movement toward the nest entrance (Schneider et al. 1986; Nieh 1998). Accordingly, workers produce and receive vibration signals year round (Schneider et al. 1986), and there is no increase in the number of signals that workers receive prior to a swarm's exodus (Rangel and Seeley 2008). By contrast, queens are vibrated by workers only in the context of swarming, with signals increasing in frequency in the weeks prior to swarm exodus and peaking immediately prior to departure (Schneider 1990a, 1991; Pierce et al. 2007). These vibratory signals increase a queen's speed of movement and stimulate egg laying, which probably helps queens to lose weight for flight while ensuring egg production (Schneider 1991). Interestingly, vibration signals are performed primarily by older workers (i.e., $>10$ days of age, Painter-Kurt and Schneider 1998; Schneider et al. 1998; Allen 1959), despite the fact that increasingly younger workers ( 2 versus 6 days old) attend the queen as swarming becomes imminent (Allen 1955).

The activities of "piping" and "buzz-running" workers are also critical for organizing the timing of a swarm's exodus. These signals are produced primarily by a small number of workers who have initiated the house-hunting process days before their swarm actually leaves the parental nest (Rangel et al. 2010). Piping bees press their abdomens to a surface (which can be another bee) and vibrate their wings, producing a strongly harmonic (i.e., high pitched) vibration that starts at a fundamental frequency of $100-200 \mathrm{~Hz}$ and rises to 200$250 \mathrm{~Hz}$ at its end (Seeley and Tautz 2001). Starting 6-10 days prior to swarming, the rate at which workers pipe the queen increases from near zero to 8-19 pipes/minute at swarm departure (Pierce et al. 2007). The frequency of worker-worker piping also increases significantly throughout the colony within the hour 
prior to swarm departure (Rangel and Seeley 2008). Finally, workers perform "buzz runs" (Lindauer 1955), in which a worker runs quickly through a crowd of bees while vibrating her wings every few seconds, producing a signal that has a fundamental frequency of $180-250 \mathrm{~Hz}$. This frequency range is similar to piping but lacks the latter's strong harmonics, thus buzz runners produce a lower pitched, "buzzy" sound (Esch 1967). The number of workers performing these buzz runs increases dramatically $\sim 15 \mathrm{~min}$ prior to swarm departure (Martin 1963; Rangel and Seeley 2008), likely as other workers join scouts in producing buzz runs (Rangel et al. 2010). This massive increase in signaling activity is associated with a dramatic increase in the mobility of workers and a decrease in their density on the comb (Rangel and Seeley 2008). It is not certain what role, if any, the queen plays in triggering a swarm's departure. It has been observed that the queen does not lead the swarm from its parental nest, but is instead often pushed out of it by workers (Simpson 1958, 1963) or the queen may fail to leave altogether, forcing workers to return to the colony and attempt to leave again at a later time (e.g., Pierce et al. 2007).

After the workers and the mother queen have departed the parental nest, they form a bivouac at a temporary location nearby. Workers who are searching for potential nest sites continue the process of scouting the area for a new home, advertising their finds, and inspecting the sites that are reported by their nestmates. Through a debate in which nest-site hunters advocate for their discoveries with waggle dances (Lindauer 1955; Seeley and Visscher 2004; Seeley et al. 2006) and inhibit dancing for competing sites with stop signals (a brief vibratory signal with a fundamental frequency of $350 \mathrm{~Hz}$ that is often accompanied by a head butt to the receiver, Michelsen et al. 1986; Nieh 1993; Seeley et al. 2012), informed members of the swarm reach a quorum for one nest site out of the multiple possible sites that are debated (see Seeley 2010 for an excellent review of worker-worker communication during nest-site selection). Once a quorum is reached, scouts stimulate workers in the swarm cluster to prepare for flight by producing piping signals, with piping starting $1-2 \mathrm{~h}$ before liftoff and increasing steadily in frequency until the moment that the swarm takes to flight (Seeley and Tautz 2001; Visscher and Seeley 2007). Piping appears to stimulate quiescent workers who maintain lower body temperatures in the swarm (presumably to conserve resources, Heinrich 1981) to warm their flight muscles to $33-35{ }^{\circ} \mathrm{C}$ (Seeley and Tautz 2001), the thoracic temperatures typical of honey bees initiating flight (Esch 1976; Heinrich 1979). Moments after the thoracic temperature of all the bees on the swarm's surface (its coolest part) reaches $35{ }^{\circ} \mathrm{C}$, the swarm dissolves and lifts into the air as workers move together to their new home (Seeley et al. 2003). Signaling scouts transition from mostly piping to mostly buzz-running as liftoff nears (i.e., 40 min beforehand), with a dramatic increase minutes beforehand in the frequency of running bees who help break up clusters of stationary workers (Rittschof and Seeley 2008). Critically, only nest-site scouts produce piping signals prior to liftoff (Visscher and Seeley 2007) and only pipers become buzz runners (Rittschof and Seeley 2008, but see Makinson et al. 2011 for the production of piping by nondancing Apis florea workers). Thus, a small group of well-informed workers are the individuals who signal to the majority of the swarm that a nest site has been chosen and it is time to move to it. The capacity for these two signals to guide the swarm at this moment is tied to their production by the same individuals: it has been hypothesized that piping "primes" the swarm for liftoff, while buzz-running is the signal that "releases" this collective behavior (Visscher and Seeley 2007).

There are similarities and differences in how the vibration signal is used during swarm departure from the parental nest and bivouac site. While the vibration signal does not seem to be associated with substantial changes in worker behavior during swarm exodus, it does play a critical role in increasing the activity of the workers in the bivouacking swarm in preparation for liftoff (Schneider et al. 1998; Visscher 
et al. 1999). It is produced by fewer than $5 \%$ of workers in a bivouac (Lewis and Schneider 2000) and, while workers deliver this signal to other workers throughout the time that a swarm house hunts, signal frequency increases significantly in the hour prior to liftoff (Visscher et al. 1999, reviewed in Schneider and Lewis 2004). Workers who are vibrated respond by increasing their rate of movement, as is their response to vibration in other contexts (see above), and by increasing their propensity to fly off the swarm face in preparation for takeoff (Visscher et al. 1999; Lewis and Schneider 2000). Furthermore, unlike the production of piping and buzzrunning signals, only a small percentage of the workers who produce vibration signals are also observed performing waggle dances (Visscher et al. 1999; Lewis and Schneider 2000) and removal of vibrating bees from swarm clusters does not affect the time required for scouts to reach a quorum threshold, but does significantly delay swarm liftoff (Donahoe et al. 2003). These studies suggest that the vibration signal is not involved in locating, debating, or selecting a new nest site, but rather in stimulating the overall activity of the swarm in preparation for liftoff.

Queen-worker interactions in the swarm cluster differ from those observed in colonies before swarm departure or among workers within swarm clusters. Queens in bivouacs are rarely vibrated, even immediately prior to liftoff, in comparison to the relatively high frequency with which they are vibrated prior to the departure of the swarm from the parental colony (Pierce et al. 2007). However, they are piped intensively by workers $1-2 \mathrm{~h}$ before liftoff, with excited nest-site scouts often forcing their way through the queen's entourage to pipe and antennate her at length (Pierce et al. 2007). The active pursuit of contact with queens in swarms by these nest-site scouts, who are often older, experienced foragers (Gilley 1998; Liang et al. 2012), is in contrast to how similarly aged workers typically behave in established colonies. Such workers do not usually seek contact with queens and, unlike young nurse-age bees who are most likely to join retinues (Seeley 1982), they show no attraction to queens or queen pheromone lures in caged assays, whereas young bees do (Grozinger and Robinson 2007). As scout bees appear to be primarily responsible for activating swarm clusters and assessing when bees are able to fly (Seeley and Tautz 2001; Rittschof and Seeley 2008), this observation suggests that scouts are either obtaining information from the queen about her flight readiness (see below for discussion of pheromone communication) or signaling her to prepare for an impending liftoff.

Upon swarm liftoff, another feat of coordination must occur: the swarm, comprised mostly of individuals who have no idea where they are going, must travel together through the open air to their selected nest site. Several hypotheses have been proposed to explain how this collective movement is executed. The hypothesis that workers produce an olfactory gradient to guide swarms (Avitabile et al. 1975) has been rejected because swarms can navigate to their new home even if worker scent glands are sealed, preventing them from releasing such odors (Beekman et al. 2006). Simulations suggest that knowledgeable house hunters could visually guide the uninformed masses by preferentially traveling in the direction of the new home (with all workers generally moving toward other workers, but avoiding collisions) (Couzin et al. 2005) or by making conspicuous and fast flights through swarms (with which naïve workers preferentially align themselves) (Lindauer 1955; Janson et al. 2005). Empirical studies of free-flying swarms show that workers do indeed "streak" above an airborne cloud of bees to visually indicate the direction of the new nest site and steer the swarm's travel (Beekman et al. 2006; Schultz et al. 2008). The behavior of these streakers is crucial for completing the swarming process, as fewer than $5 \%$ of bees in the swarm have visited their future nest site during house hunting (Seeley and Buhrman 1999). When the swarm reaches the nest site, scouts settle at its entrance; both the visual cluster of scout bees and pheromones (see below) attract the remaining bees (Ambrose 1976; Seeley et al. 1979; Beekman et al. 2006). 
Back in the parental nest, the departure of the original queen means that a new queen must take over. If a colony is strong enough after the first (or prime) swarm leaves, it may issue other swarms (one or more "afterswarms") (reviewed by Winston 1987). Queen replacement usually occurs within a matter of days when a virgin queen (often the first one to emerge from her cell after all swarms have been cast) takes over the remnant colony, eliminating her rivals by stinging them in their cells or fighting with them once they have emerged (Allen 1956; Fletcher 1978a; Gilley 2001; Gilley and Tarpy 2005; Schneider and DeGrandi-Hoffman 2008). However, if a colony issues one or more afterswarms, the replacement process takes longer and will likely involve dueling between virgins (Allen 1956; Fletcher 1978a; Gilley 2001; Gilley and Tarpy 2005; Schneider and DeGrandi-Hoffman 2008). Adult virgin queens will call to one another with different forms of piping called tooting and quacking (Michelsen et al. 1986) and then battle (grappling, stinging, and spraying hindgut contents, which contain the repellant $o$ aminoacetophenone) (Page et al. 1988; Bernasconi et al. 2000; Gilley 2001; Schneider et al. 2001; Tarpy and Fletcher 2003; Gilley and Tarpy 2005). Worker signals play a role in how queen replacement unfolds in two ways. First, workers vibrate emerged virgins, which causes them to increase their rate of activity and produce more queen-directed pipes (Gilley 2001; Schneider et al. 2001). Secondly, workers vibrate queen cells (Fletcher 1978a, b; Bruinsma et al. 1981; Schneider et al. 2001), which, in combination with workers resealing cell caps as they are cut open by emerging virgins and the freezing response of sealed virgins to tooting pipes from free queens, slows emergence of virgins from cells (Grooters 1987). These signal-dependent interactions coordinate the timing of the release of virgin queens with the timing of the departure of prime swarms and afterswarms, ensuring that a single queen leaves with each swarm and that only one queen takes over the remnant colony at the end of the swarming process.

\section{CHEMICAL SIGNALS THAT C O O R D I N A T E S WA R M PREPARATION AND MOVEMENT}

Chemical signals, in the form of pheromones produced by both queens and swarming workers, also play a critical role in regulating different stages of the swarming process. However, substantially less is known about these chemical signals. Outside of the production of Nasonov by swarming workers (reviewed in Blum 1992; Free 1987), virtually nothing has been reported about novel chemicals that swarming workers may produce. Nasonov pheromone is produced by a small scent gland located between a worker's fifth and sixth abdominal tergites (McIndoo 1915). It consists primarily of seven terpenoids, $(Z)$ - and $(E)$ citral, nerol, geraniol, nerolic acid, geranic acid and (E,E)-farnesol (Pickett et al. 1980), and functions at many stages during swarming. Lures with both Nasanov and components of queen pheromone (but not Nasanov alone) induce clustering of queenless workers (Ferguson et al. 1979; Free et al. 1981a) and nesting boxes marked with Nasanov pheromone are more attractive to swarms (Free et al. 1981b; Schmidt et al. 1993; Schmidt 2001). Interestingly, though scout bees release Nasanov upon arriving at their new nest's entrance, the remaining bees will land with equal rapidity even if the scouts' Nasanov glands are sealed shut, suggesting that visual cues provided by clustered scouts help to facilitate this process (Beekman et al. 2006). However, it takes these swarms significantly longer to actually enter their new home.

Although there is little evidence that queens produce nonchemical signals during the swarming process (save for communication between daughter queens seeking to take over the parental nest, as discussed above and reviewed in Michelsen et al. 1986), queens do produce chemical signals that regulate many aspects of the swarming process. Different suites of chemicals produced in multiple glands (the best studied of which are the mandibular, Dufour's, tergal, and tarsal glands) and extracts from queen feces and cuticles have all been 
shown to elicit behavioral responses from workers in multiple contexts (Lensky and Slabezki 1981; Slessor et al. 1988; Page et al. 1988; Breed et al. 1992; Wossler and Crewe 1999a, 1999b; Katzav-Gozansky et al. 2003; Keeling et al. 2003; reviewed in Slessor et al. 2005; Grozinger in press). The mandibular and tarsal glands have been studied most extensively in terms of their role in coordinating swarming behavior. The mandibular glands produce $>20$ compounds, five of which (termed queen mandibular pheromone (QMP)) have been demonstrated to elicit many of the same responses as live queens (Slessor et al. 1988; Grozinger et al. 2003; Hoover et al. 2003). The three main active components of QMP are 9keto-2 (E)-decenoic acid (9-ODA), and R-(-)and $\mathrm{S}-(+)-9$-hydroxy-2 (E)-decenoic acid $( \pm 9$ HDA). These five QMP compounds synergize with an additional four compounds (the ninecomponent blend is termed queen retinue pheromone (QRP)) to attract bees over short distances, though the effects of QRP on swarming have not been examined (Keeling et al. 2003). In contrast, we know little about the chemical composition of the tarsal glands; these substances are deposited as the queen walks, so are often called "foot-print pheromones" (Lensky and Slabezki 1981). Interestingly, two chemicals found in QRP have also been identified in the legs or tarsal glands of wasps and bumble bees, where they may function to mark nest entrances or food sources in these species (Butler et al. 1969; Schmitt et al. 1991; Hefetz et al. 1996; Moneti et al. 1997).

Queen pheromone plays a significant role in regulating the initiation of new queen rearing, which is the first stage of the swarming process. It is hypothesized that a reduction in the "activity" of queen pheromone triggers the initiation of queen rearing (reviewed in Simpson 1958; Winston 1980, 1987). This reduction in activity could be because of reduced production of the pheromone, reduced concentration (in terms of units of pheromone/worker) in the colony as the population increases, reduced transmission to the edges of the colony where the queen cells are preferentially built (because workers must physically transfer queen pheromone through the nest in order for queen rearing to be inhibited, Seeley 1979), or reduced worker sensitivity to the pheromone. It seems unlikely that reduced production of the pheromone is responsible, because whole body extracts from swarming and nonswarming queens contain equivalent quantities of 9-ODA (Seeley and Fell 1981) and are equally effective in inhibiting new queen rearing by groups of queenless workers caged with honeycomb containing young larvae (Butler 1960). Changes in worker response thresholds have not been examined, though there are significant differences in expression levels of genes associated with sensory processing in workers that depart with the swarm versus those that remain in the colony (Richards et al. unpublished data). Reduction in concentration or transmission of queen pheromone seems to be the most likely signal. While extracts of live queens, synthetic QMP, or 9-ODA can all inhibit initiation of emergency queen rearing in queenless colonies (Winston et al. 1989; Engels et al. 1993; Melathopoulous et al. 1996; Pettis et al. 1997), adding 9-ODA lures to congested queenright colonies does not effectively inhibit queen rearing during the swarming season (Boch and Lensky 1976). However, applying QMP as a spray rather than a stationary lure does delay swarming in congested colonies (Winston et al. 1991). Similarly, the addition of both tarsal and mandibular gland extracts to the edges of the comb of congested colonies significantly reduced the production of queen cells, but either pheromone alone was ineffective (Lensky and Slebezki 1981). Indeed, in congested colonies, queens spend significantly less time on the outer edges of the nest (Lensky and Slebezki 1981), thereby reducing transmission to workers of footprint pheromones and other contact pheromones. Naumann et al. (1993) found that a smaller proportion of workers had detectable levels of pheromone on their bodies in large colonies. Thus, pheromone transfer via movement of the queen or among workers throughout the 
colony is likely compromised at high levels of congestion, and may trigger the initiation of new queen rearing.

Queen pheromones also ensure that the queen successfully accompanies swarming workers to their new nest site. The area spanned by a migrating swarm of bees is vast: flying swarms of 11,000 bees can occupy a space that is 8-12 $\mathrm{m}$ long, 6-8 $\mathrm{m}$ wide, and 3-4 $\mathrm{m}$ high (Beekman et al. 2006). The presence of a queen in an airborne swarm improves the moving swarm's cohesion-swarm clusters that liftoff without a queen are much more dispersed, spanning a diameter of up to $60 \mathrm{~m}$ (Morse 1963). Furthermore, if the queen is prevented from accompanying the flying workers, workers will return to the last place that they clustered with her (Avitabile et al. 1975) or move to her new location if she is placed nearby (Simpson 1963; Morse 1963), thereby ensuring that the queen remains with the swarm to establish the new nest. Some components of queen pheromone play a clear role in informing swarms of the presence of their queen. When queens are prevented from lifting off with swarms but some workers are marked with 9-ODA, workers will relocate to their new nest site without returning for their abandoned queens (Avitabile et al. 1975). Swarms will also cluster stably around a lure impregnated with 9-ODA and/or 9-HDA (Butler et al. 1964; Butler and Simpson 1967; Winston et al. 1982). However, while 9ODA, 9-HDA, and QMP are attractive to workers from queenless swarms, whole-queen extracts or live queens are significantly more attractive (Boch et al. 1975; Winston et al. 1989). Thus, additional queen-produced compounds may be involved in swarm cohesion, attraction, and migration. Studies from our group have found that during liftoff of swarm clusters $(n=17$ swarms that were created according to the methods of Seeley and Buhrman 1999), queens produce additional volatile components that are not found in the same queens when they are in their colonies or in bivouacs prior to the initiation of house hunting, and swarming workers are more attracted to the volatiles produced by a swarming queen versus a queen from an established colony (Richards et al. unpublished data). These results suggest that queens can modify their pheromonal blend relatively rapidly under different environmental or social conditions and that this modified blend may play a role in swarm attraction and cohesion, or may signal the initiation of swarm liftoff. Thus, queens do not appear to be passive participants in the swarming process, but instead produce a suite of chemicals that help to organize it.

\section{PHYSIOLOGICAL AND GENOMIC MECHANISMS UNDERLYING SWARMING}

Like workers in an established colony that exhibit age-based division of labor (with younger nurse bees performing brood care and older forager bees retrieving resources from the environment), tasks performed by workers in a swarming colony are also divided among three distinct classes: workers in swarms who scout, workers in swarms who do not scout, and nonswarming workers who remain in the parental nest. Mounting evidence suggests that, like nurses and foragers, these bees are distinct at the genomic, physiological, and behavioral level. Scouts tend to be older than the other bees in a swarm, typically in the age range of young foragers (Gilley 1998). Interestingly, nest-site scouts are likely to function as food scouts who search for new floral sources, suggesting that these bees are "novelty seekers" (Liang et al. 2012). These behavioral differences are underpinned by differences in global patterns of gene expression between scouts and nonscouts, including expression of several genes involved in biogenic amine signaling (Liang et al. 2012). Treating workers with glutamate and octopamine increases scouting activity (Liang et al. 2012), suggesting that differences in neurosignalling pathways play a key role in stimulating this behavior.

Approximately three quarters of workers depart with a swarm, while the remaining workers stay in the colony to rear the new queen (Martin 1963; Getz et al. 1982). Interestingly, even bees 
relatively newly introduced into colonies ( $\sim 2$ days before swarm departure) can join swarms, suggesting that little time is needed to prepare for swarming (Simpson and Riedel 1964). The factors underlying the decision to stay or to swarm have not been elucidated, but overall, swarming bees are substantially younger than nonswarming bees (Butler 1940; Winston and Taylor 1980; Winston et al. 1981; Gilley 1998). The ages of the majority of the bees in a swarm correspond to the ages of bees typically performing nursing behavior/brood care in established colonies (Winston 1987; Seeley 1995). For example, Winston and Taylor (1980) found that the mean age of swarming bess is 10 days of age for Africanized workers and 15 days of age for European workers. Interestingly, in addition to being chronologically younger, swarming workers may also be physiologically younger. Levels of juvenile hormone, which pace behavioral maturation in worker honey bees (foragers have significantly higher levels than nurses, and treatment with juvenile hormone accelerates maturation, Sullivan et al. 2000), are lower in $\geq 16$-day-old bees from pre-swarming colonies versus nonswarming colonies (Zeng et al. 2005).

Having swarms consist primarily of younger bees could be beneficial for many reasons. First, many of the tasks that need to be performed at the new nest site (comb building and brood rearing) are typically performed by younger bees (as noted by Butler 1940). Second, a younger swarm should lose relatively fewer bees over the time that it takes to start building comb and for the first generation of new workers emerge ( 1 month) (Winston 1987). Third, workers in swarms do not forage for food until they relocate to their new nest site, thus they must rely on nutrient reserves that they carry in their bodies. Though workers fill their honey stomachs in preparation for swarm departure (Combs 1972; Leta et al. 1996), younger nurse bees tend to have greater nutritional stores than older forager bees, including greater quantities of lipids (Toth and Robinson 2005), glycogen (Leta et al. 1996), and hemolymph levels of the storage protein vitellogenin (Fluri et al. 1982). Surprisingly, hemolymph sugar titers (trehalose, glucose, and fructose) and body glycogen reserves are not significantly different in same-aged workers from pre-swarm colonies versus nonswarm colonies (Leta et al. 1996). Levels of vitellogenin RNA in fat bodies, however, are significantly higher in bees who depart with (natural) swarms compared with those who remain in the parental colony (Richards et al. unpublished data).

Aside from differences in overall age distribution, are there other factors that distinguish swarming workers from nonswarming workers? There is evidence that heritable genetic differences may underlie the propensity of workers to join swarms because workers in some patrilines are more likely to swarm than workers in other patrilines (Getz et al. 1982; Kryger and Moritz 1997). Furthermore, assessment of patterns of global gene expression in the brains of pooled groups of workers that depart with swarms versus those that remain in the parental colony reveal that there are $\sim 140$ differentially expressed genes between the two groups (Richards et al. unpublished data), but this is much fewer than $\sim 1,200$ genes that are differentially expressed between scouts and nonscout foragers (Liang et al. 2012). Genes associated with nursing behavior were significantly upregulated in the brains of bees joining swarms, indicating that, in terms of brainexpression patterns, swarming bees are also more "nurse-like" than nonswarming bees (Richards et al. unpublished data). Studies of brain gene expression patterns in bees performing the vibration signal (in a nonswarming context) versus matched, nonsignaling forager bees, also revealed that this behavior is correlated with differential expression of 900 genes (Alaux et al. 2009), which suggests that bees performing the vibration signal may also be in a distinct neurophysiological state compared with nonsignaling bees. Thus, though swarms generally appear to consist of thousands of bees acting in concert, there are undoubtedly subsets of bees in each one with distinct neurogenomic states and behaviors. Interestingly, there is no evidence of nepotism during queen replacement and swarming behavior (Gilley 2003; Rangel et al. 2009), which suggests that workers cannot distinguish between kin and 
non-kin during this process, and thus the propensity to swarm appears to be based on an individual's age, genotype, and neurogenomic and physiological state.

\section{EVOLUTION OF SWARMING BEHAVIOR}

Reproductive swarming behavior in honey bees is likely related to nest relocation behavior. Most social insect colonies, including bees, ants, wasps, and termites, have the ability to move to new nest sites in response to various cues and under different circumstances (reviewed in McGlynn 2012). In honey bees, nest relocation is termed "absconding." An absconding colony will abandon its nest, often consuming any remaining food and cannibalizing brood before relocating to a new site (reviewed in Hepburn 2006). "Simple absconding" can occur rapidly in response to an acute stimulus such as predation or physical destruction and disturbance of the nest, while "prepared absconding" (hereafter termed "migration") occurs as part of normal seasonal migration in response to resource limitation (terms defined in Hepburn 2006). While all Apis species must reproductively swarm (because queens are incapable of independently founding a nest and workers cannot mate), simple absconding and migration are rarely observed in temperate Apis mellifera subspecies, but are quite common in tropical $A$. mellifera subspecies, as well as other tropical Apis species, including A. dorsata, A. florea, A. cerana, A. andreniformis, and $A$. laboriosa (reviewed in Matsuka et al. 1998; Hepburn 2006; Duangphakdee et al. 2012). Seasonal migration occurs regularly in tropical Apis species, with the majority of colonies relocating nest sites throughout the year (Venkatesh and Reddy 1989; Schneider 1990a; Sihag 1998).

It is not clear if reproductive swarming in honey bees evolved from migratory behavior, or vice versa, because Apis species display both forms of behavior and related species exhibit one behavior or the other. Genomic studies indicate that temperate A. mellifera subspecies evolved from populations that migrated out of subtropical Africa (Ruttner 1987; Hepburn and Radloff 1998; Whitfield et al. 2006a), and because African subspecies both migrate and swarm while temperate subspecies only swarm, it suggests that temperate subspecies have largely lost migratory behavior. Stingless bees (Meliponini) also perform reproductive swarming, in which a virgin queen and a subset of the workers establish a new nest site in close proximity to the old nest, initially relying on the parental colony for resources (reviewed in Roubik 2006; Michener 2013). However, stingless bees are unable to migrate (Roubik 2006), though cases of simple absconding have been reported (Inoue et al. 1984). Temperate wasps species that do not reproduce by swarming can abscond, while some tropical wasp species abscond, migrate, and reproductively swarm (West-Eberhard 1982). Finally, in ants, reproduction through colony fission (versus independent founding by a queen) is thought to be a derived trait that is expressed in only a subset of species (Peeters and Ito 2001), whereas many ant species are capable of relocating their nests (McGlynn 2012), suggesting this behavior is relatively older. Thus, the ability to store and transport resources over long distances in reproductive swarms may have facilitated the evolution of migratory behavior, or vice versa, but these phenomena likely evolved independently multiple times.

If reproductive swarming is related to migratory behavior, then it would be predicted that many of the same social, physiological, and molecular mechanisms regulate these two processes. While most of these parameters have not been well investigated for migratory behavior, those that have reveal both commonalities and differences. Like swarming colonies (see above), migrating A. mellifera scutellata colonies in Botswana experience an increase in population size and food stores compared with nonmigrating colonies (Schneider and McNally 1992), but migrating colonies of Africanized bees in South America do not (Winston and Taylor 1980). While egg laying can be reduced (Allen 1955, 1956) or continuous (Pierce et al. 2007) in colonies of European honey bees immediately prior to 
reproductive swarming, queens in pre-migratory A. mellifera scutellata colonies cease egg laying altogether (Schneider 1990a) and a significant reduction in brood rearing 3-4 weeks before departure is indicative of preparations for migration (Winston 1979; Schneider 1990b; Schneider and McNally 1992). Furthermore, there are significantly fewer interactions (feeding, harassing) observed between workers and pre-migratory A. mellifera scutellata queens versus pre-swarming queens, and pre-migratory queens are not vibrated at all (Schneider 1990a). While migrating and reproductive swarming $A$. mellifera scutellata workers both engorge on honey prior to departure, migrating workers carry relatively larger volumes, enough to allow them to fly almost twice as far as swarming workers (121 versus $71 \mathrm{~km}$, respectively) (Otis et al. 1981). Migrating workers also perform "migration dances," which resemble waggle dances in that a worker moves her abdomen side-to-side while walking forward in a straight line, but rather than returning to her starting position, she simply walks forward and then restarts the waggle (Koeniger and Koeniger 1980; Dyer and Seeley 1994; Schneider and McNally 1994; Dyer 2002; Lewis and Schneider 2008). The distances communicated by migration dances are significantly greater than what is communicated by foraging-associated waggle dances, and the variation in dances performed by an individual and between individuals is substantial (Schneider and McNally 1994; Lewis and Schneider 2008). In migrating A. mellifera scutellata colonies, swarms travel in roughly the same direction indicated by the migrating dances, so dances may serve to prepare a colony to migrate and/or inform workers of the general direction of travel (Schneider and McNally 1994). Interestingly, 2 weeks prior to reproductive swarming, workers in European honey bee colonies also perform migration dances, but substantially fewer workers perform them (4-8 dances/colony versus 20-75 dances/colony for migrating A. mellifera scutellata) and dances are not oriented toward the direction of travel (Lewis and Schneider 2008). Thus, it is unclear whether these dances serve a function or are simply an evolutionary remnant of the loss of migratory behavior in temperate A. mellifera (Lewis and
Schneider 2008). Overall, although there are some common elements in the preparation for reproductive swarming and migration (worker engorgement, migration dances), worker-queen interactions for each phenomenon are quite distinct.

While the genomic and physiological pathways underpinning migratory behavior have not been characterized, and those regulating reproductive swarming behavior are only beginning to be characterized, it is likely that these pathways are related to those involved in overwintering in temperate honey bee subspecies, estivation in tropical honey bee subspecies, and, finally, diapause in solitary insects. During all of these processes, individuals experience conditions in which they cannot readily forage for nutritional resources. "Diapause" is a common response of many solitary insect species to stressful environmental conditions in which nutritional resources are limited. Diapausing insects enter a period of dormancy marked by increased physiological nutrient stores, reduced reproduction, metabolism, and activity, and in some cases, increased lifespan (reviewed in Denlinger 1986, 2002; MacRae 2010; Hahn and Denlinger 2011). These pleiotropic changes appear to be due to modifications in core metabolic pathways, including insulin signaling (Denlinger 2002; Kankare et al. 2010; MacRae 2010). It is possible that similar pathways underlie swarming, migrating, and overwintering behavior in honey bees. Indeed, swarming and overwintering workers have a more nurse-like physiology, they are longer lived, and have increased nutritional stores (Butler 1940; Winston and Taylor 1980, Winston et al. 1981, Fluri et al. 1982; Gilley 1998; Kunert and Crailsheim 1988; Huang and Robinson 1995; Page and Peng 2001; Zeng et al. 2005). Finally, similar social cues may be used to trigger these processes. Both migrating and overwintering bees experience a decline in brood production (Winston 1979; Schneider 1990a, 1990b; Schneider and McNally 1992; Mattila and Otis 2007), and reproductively swarming bees experience a complete break in brood production as they establish a new nest. In established colonies, removal of young bees or 
brood arrests the development of older bees, such that they remain in the nursing state longer (Fluri et al. 1982; Huang and Robinson 1996). Thus, linking changes in nutritional and social cues to changes in worker physiology and longevity may give colonies the ability to survive a variety of different conditions in which brood rearing is interrupted or otherwise not possible (Maurizio 1950; Mattila and Otis 2007).

\section{FUTURE DIRECTIONS}

Swarming in honey bees provides a fascinating example of collective behavior involving thousands of individuals in an array of different behavioral and physiological states who cooperate to execute an intricate behavioral process that can span multiple locations, phases, and days. Decades of sophisticated research have provided a detailed understanding of the numerous behavioral signals that are used to coordinate this process. However, our understanding of the chemical signals that are associated with these behaviors and the molecular mechanisms that underlie them is in its infancy, and the array of techniques that are available to study these phenomena have not been fully exploited. For example, using recently developed, sensitive analytical techniques (solid phase microextraction) to nondestructively sample the volatile chemicals that are produced by individuals while they behave naturally, we demonstrated that queens are not simply passive participants in the swarming process, and in fact provide important signals that help to coordinate swarming (Richards et al. unpublished data). While it remains to be determined whether other physical and auditory signals accompany these chemical signals, this recent example suggests that there are likely many unidentified signals produced by individuals within swarms that help coordinate the swarming process. Furthermore, there is evidence to suggest that the response of workers to chemical signals can differ greatly in established colonies versus swarms. For example, in established colonies, 9ODA only weakly attracts workers from short (centimeters) distances (Slessor et al. 1988; Grozinger et al. 2007b), while it appears to inform workers of a queen's presence in dispersed, flying swarms (Avitabile et al. 1975). Furthermore, in established colonies, foragers do not interact with the queen and are not attracted to queen pheromone (Seeley 1982; Grozinger and Robinson 2007), while forager-aged scout bees seek out and physically contact the queen in swarm clusters (Pierce et al. 2007). Thus, there may be an entire network of both modified and unique nonchemical and chemical signals that are exchanged within a swarm that were previously impossible to capture using traditional analytical tools.

Similarly, our ability to monitor genome-wide expression patterns in tissues of individual bees can provide us with a very detailed understanding of the types of bees that make up a swarm, and a better understanding of how they interact. Genomic studies have already demonstrated that distinct neurogenomic states are exhibited by scouts versus nonscouts (Liang et al. 2012), bees producing vibration signals versus those who do not (Alaux et al. 2009), and bees who depart with swarms versus those who stay in the nest (Richards et al. unpublished data). Continued investigation at the genomic and physiological levels can help us to understand why only a small handful of individuals produce the key signals that coordinate the swarming process, and why only a subset of receivers actually respond behaviorally to these signals in some of its phases (i.e., exodus) and all receivers respond in others (i.e., swarm liftoff). Furthermore, we can determine whether swarming behavior is dynamic at the neurogenomic level, with different sets of genes potentially coordinating different stages of the swarming process. We will be able to determine whether a large population of nonscout, nonsignaling bees in a swarm enter a similar state regardless of their previous experience or physiological state, or whether a swarm is instead made up of a myriad of different types of bees, each with different proclivities in terms of their sensory thresholds, their behaviors, and the tasks they initially perform in the new nest. A genomic approach will also allow us to determine whether common genes and pathways underlie the apparently similar behaviors and physiological states that are associated with reproductive swarming, 
overwintering in temperate honey bees, and migration and estivation in tropical honey bees. If common genes and gene pathways are indeed associated with these distinct processes, the next step will be to determine whether these genes also mediate diapause in solitary species. If so, then it would suggest that ancient pathways regulating responses to nutritional and environmental stress have been co-opted to allow honey bees to adapt to a wide array of ecological conditions.

\section{ACKNOWLEDGMENTS}

The authors would like to thank Nick Sloff and Harland Patch (Penn State University) for assistance with graphical design of Figure 1, and Jonathan Snow (Barnard College) for the line drawing of the hive. This review was supported by a National Science Foundation CAREER grant to CMG, a US-Israel Binational Science Foundation grant to CMG (and A. Hefetz), and a Wellelsey College Brachman-Hoffman grant and Knafel Endowed Chair in the Natural Sciences to HRM.

Des molécules aux sociétés: mécanismes régulant le comportement d'essaimage chez les abeilles (Apis spp.)

comportement collectif / essaimage / communication chimique / physiologie / génomique / abeille

Von Molekülen zum Sozialverhalten: Mechanismen die das Schwarmverhalten bei Honigbienen (Apis spp.) regulieren

Sozialverhalten / Schwärmen / chemische Kommunikation / Physiologie / Genomik / Honigbiene

\section{REFERENCES}

Alaux, C., Duong, N., Schneider, S.S., Southey, B.R., Rodriguez-Zas, S., Robinson, G.E. (2009) Modulatory communication signal performance is associated with a distinct neurogenomic state in honey bees. PLoS ONE 4(8), e6694

Allen, M.D. (1955) Observations of honeybees attending their queen. Anim. Behav. 3, 66-69

Allen, M.D. (1956) The behaviour of honeybees preparing to swarm. Anim. Behav. 4(1), 14-22
Allen, M.D. (1959) The occurrence and possible significance of the "shaking" of honeybee queens by workers. Anim. Behav. 7, 66-69

Ambrose, J.T. (1976) Swarms in transit. Bee World 57, 101-109

Anholt, R.R., Mackay, T.F. (2012) Genetics of aggression. Annu. Rev. Genet. 46, 145-164

Avitabile, A., Morse, R.A., Boch, R. (1975) Swarming honey bees guided by pheromones. Ann. Entomol. Soc. Am. 68, 1079-1082

Beekman, M., Fathke, R.L., Seeley, T.D. (2006) How does an informed minority of scouts guide a honeybee swarm as it flies to its new home? Anim. Behav. 71, 161-171

Ben-Shahar, Y., Robichon, A., Sokolowski, M.B., Robinson, G.E. (2002) Influence of gene action across different time scales on behavior. Science 296(5568), 741-744

Bernasconi, G., Ratnieks, F.L.W., Rand, E. (2000) Effect of "spraying" by fighting honey bee queens (Apis mellifera L.) on the temporal structure of fights. Insectes Soc. 47, 21-26

Biesmeijer, J.C. (2003) The occurrence and context of the shaking signal in honey bees (Apis mellifera) exploiting natural food sources. Ethology 109(12), 1009-1020

Blum, M.S. (1992) Honey bee pheromones. In: Graham, J.M. (ed.) The hive and the honey bee, pp. 269-361. Dadant \& Sons, Hamilton

Boch, R., Lensky, Y. (1976) Pheromonal control of queen rearing in honey bee colonies. J. Apic. Res. 15, 59-62

Boch, R., Shearer, D.A., Young, J.C. (1975) Honey bee pheromones: field tests of natural and artificial queen substance. J. Chem. Ecol. 1(1), 133-148

Breed, M.D., Stiller, T.M., Blum, M.S., Page, R.E. (1992) Honeybee nestmate recognition: effects of queen fecal pheromones. J. Chem. Ecol. 18, 16331640

Bruinsma, O., Van Kruijt, J.P., Dusseldorp, W. (1981) Delay of emergence of honey bee Apis mellifera queens in response to tooting sounds. Proc. K. Ned. Akad. van Wet. Ser. C Biol. Med. Sci. 84, 381-387

Butler, C.G. (1940) The ages of bees in a swarm. Bee World 21, 9-10

Butler, C.G. (1960) The significance of queen substance in swarming and supersedure in honey bee (Apis mellifera L.) colonies. Proc. R. Entomol. Soc. London A 35, 129-132

Butler, C.G., Simpson, J. (1967) Pheromones of the queen honeybee (Apis mellifera L.) which enable her workers to follow her when swarming. Proc. R. Entomol. Soc. A 42(10-12), 149-154

Butler, C.G., Callow, R.K., Chapman, J.R. (1964) 9hydroxydec-trans-2-enoic acid, a pheromone stabilizing honeybee swarms. Nature 201(4920), 733 
Butler, C.G., Fletcher, D.J.C., Watler, D. (1969) Nestentrance marking with pheromones by the honeybee Apis mellifera L., and by a wasp Vespula vulgaris L. Anim. Behav. 17(1), 142-147

Cao, T.T., Hyland, K.M., Malechuck, A., Lewis, L.A., Schneider, S.S. (2007) The influence of the vibration signal on worker interactions with the nest and nest mates in established and newly founded colonies of the honey bee, Apis mellifera. Insectes Soc. 54, 144-149

Cao, T.T., Hyland, K.M., Malechuk, A., Lewis, L.A., Schneider, S.S. (2009) The effect of repeated vibration signals on worker behavior in established and newly founded colonies of the honey bee, Apis mellifera. Behav. Ecol. Sociobiol. 63, 521-529

Clayton, D.F. (2004) Songbird genomics: methods, mechanisms, opportunities, and pitfalls. Ann. N. Y. Acad. Sci. 1016, 45-60

Combs Jr., G.F. (1972) The engorgement of swarming worker honeybees. J. Apic. Res. 11(3), 121-128

Couzin, I.D., Krause, J., Franks, N.R., Levin, S.A. (2005) Effective leadership and decision-making in animal groups on the move. Nature 433, 513-516

Cummings, M.E. (2012) Looking for sexual selection in the female brain. Philos. Trans. R. Soc. Lond. B Biol. Sci. 367(1600), 2348-2356

Denlinger, D.L. (1986) Dormancy in tropical insects. Annu. Rev. Entomol. 31, 239-264

Denlinger, D.L. (2002) Regulation of diapause. Annu. Rev. Entomol. 47, 93-122

Donahoe, K., Lewis, L.A., Schneider, S.S. (2003) The role of the vibration signal in the house-hunting process of honey bee (Apis mellifera) swarms. Behav. Ecol. Sociobiol. 54, 593-600

Duangphakdee, O., Hepbur, H.R., Radloff, S.E., Pirk, C.W.W., Rodim, P., Wongsiri, S. (2012) Waggle dances in absconding colonies of the red dwarf honeybee, Apis florea. Insectes Soc. 59, 571-577

Dyer, F.C. (2002) The biology of the dance language. Annu. Rev. Entomol. 47, 917-949

Dyer, F.C., Seeley, T.C. (1994) Colony migration in the tropical honey bee Apis dorsata F. (Hymenoptera: Apidae). Insectes Soc. 41, 129-140

Engels, W., Adler, A., Rosenkranz, P., Lübke, G., Francke, W. (1993) Dose-dependent inhibition of emergency queen rearing by synthetic 9-ODA in the honey bee, Apis mellifera carnica. J. Comp. Physiol. B. 163, 363-366

Esch, H. (1967) The sound produced by swarming honey bees. Z. Vergl. Physiol. 56, 408-411

Esch, H. (1976) Body temperature and flight performance of honey bees in a servomechanically controlled wind tunnel. J. Comp. Physiol. 109, 264-277

Fefferman, N.H., Starks, P.T. (2006) A modeling approach to swarming in honey bees (Apis mellifera). Insectes Soc. 53(1), 37-45

Ferguson, A.W., Free, J.B., Pickett, J.A., Winder, M. (1979) Techniques for studying honeybee pheromones involved in clustering, and experiments on the effect of Nasonov and queen pheromones. Physiol. Entomol. 4, 339-344

Fletcher, D.J.C. (1978a) The influence of vibratory dances by worker honeybees on the activity of virgin queens. J. Apic. Res. 17, 3-13

Fletcher, D.J.C. (1978b) Vibration of queen cells by worker honeybees and its relation to the issue of swarms with virgin queens. J. Apic. Res. 17, 14-26

Fluri, P., Luscher, M., Wille, H., Gerig, L. (1982) Changes in the weight of the pharyngeal gland and haemolymph titres of juvenile hormone, protein and vitellogenin in worker honey bees. J. Insect Physiol. 28, 61-68

Free, J.B. (1987) Pheromones of social bees. Cornell University Press, Ithaca

Free, J.B., Ferguson, A.W., Pickett, J.A. (1981a) Evaluation of the various components of the Nasanov pheromone used by clustering honeybees. Physiol. Entomol. 6(3), 263-268

Free, J.B., Pickett, J.A., Ferguson, A.W., Smith, M.C. (1981b) Synthetic pheromones to attract honeybee (Apis mellifera) swarms. J. Agr. Sci. 97(2), 427-431

Gahl, R.A. (1975) The shaking dance of honeybee workers: evidence for age discrimination. Anim. Behav. 23, 230-232

Gary, N.E. (1962) Chemical mating attractants in the queen honey bee. Science 136, 773-774

Getz, W.M., Brückner, D., Parisian, T.R. (1982) Kin structure and the swarming behavior of the honey bee Apis mellifera. Behav. Ecol. Sociobiol. 10, 265-270

Gilley, D.C. (1998) The identity of nest-site scouts in honey bee swarms. Apidologie 29(3), 229-240

Gilley, D.C. (2001) The behavior of honey bees (Apis mellifera ligustica) during queen duels. Ethology 107, 601-622

Gilley, D.C. (2003) Absence of nepotism in the harassment of dueling queens by honeybee workers. Proc. R. Soc. Lond. B 270(1528), 2045-2049

Gilley, D.C., Tarpy, D.R. (2005) Three mechanisms of queen elimination in swarming honey bee colonies. Apidologie 36, 461-474

Gilley, D.C., DeGrandi-Hoffman, G., Hooper, J.E. (2006) Volatile compounds emitted by live European honey bee (Apis mellifera) queens. J. Insect Physiol. 2, 520-527

Grooters, H.J. (1987) Influences of queen piping and worker behaviour on the timing of emergence of honey bee queens. Insectes Soc. 34, 181-193

Grozinger, C.M. (in press) Honey bee pheromones. In: J. Graham (ed) The hive and the honey bee, Indianapolis, Dadant. $42 \mathrm{p}$

Grozinger, C.M., Robinson, G.E. (2007) Endocrine modulation of a pheromone responsive gene in the honey bee brain. J. Comp. Bio. A 193(4), $461-470$ 
Grozinger, C.M., Sharabash, N.M., Whitfield, C.W., Robinson, G.E. (2003) Pheromone-mediated gene expression in the honey bee brain. Proc. Natl. Acad. Sci. USA 100(Suppl 2), 14519-14525

Grozinger, C.M., Fan, Y., Hoover, S.E., Winston, M.L. (2007a) Genome-wide analysis reveals differences in brain gene expression patterns associated with caste and reproductive status in honey bees (Apis mellifera). Mol. Ecol. 16(22), 4837-4848

Grozinger, C.M., Fischer, P., Hampton, J.E. (2007b) Uncoupling primer and releaser responses to pheromone in honey bees. Naturwissenschaften 94(5), 375-379

Hahn, D.A., Denlinger, D.L. (2011) Energetics of insect diapause. Annu. Rev. Entomol. 56, 103-121

Hefetz, A., Taghizadeh, T., Francke, W. (1996) The exocrinology of the queen bumble bee Bombus terrestris (Hymenoptera: Apidae, Bombini). Z. Naturforsch. 51, 409-422

Heinrich, B. (1979) Thermoregulation of African and European honeybees during foraging, attack and hive exits and returns. J. Exp. Bio. 80, 217-229

Heinrich, B. (1981) The mechanisms and energetics of honeybee swarm temperature regulation. J. Exp. Biol. 91, 25-55

Hepburn, H.R. (2006) Absconding, migration and swarming in honeybees: an ecological and evolutionary perspective. In: Kipyatkov, V.E. (ed.) Life cycles in social insects: behavior, ecology and evolution, pp. 121-135. St. Petersburg University Press, St. Petersburg

Hepburn, H.R., Radloff, S.E. (1998) Honeybees of Africa, p. 386. Springer, New York

Hoover, S.E.R., Keeling, C.I., Winston, M.L., Slessor, K.N. (2003) The effect of queen pheromones on worker honey bee ovary development. Naturwissenschaften 90, 477-480

Huang, Z.Y., Robinson, G.E. (1995) Seasonal changes in juvenile hormone titers and rates of biosynthesis in honey bees. J. Comp. Physiol. B. 165, 18-28

Huang, Z.Y., Robinson, G.E. (1996) Regulation of honey bee division of labor by colony age demography. Behav. Ecol. sociol. 39(3), 147-158

Inoue, T., Sakagami, S., Salmah, S., Nukmal, N. (1984) Discovery of successful absconding in the stingless bee Trigona (Tetragonula) laeviceps. J. Apic. Res. 23, 136-142

Janson, S., Middendorf, M., Beekman, M. (2005) Honeybee swarms: how do scouts guide a swarm of uninformed bees? Anim. Behav. 70, 349-358

Kankare, M., Salminen, T., Laiho, A., Vesala, L., Hoikkla, A. (2010) Changes in gene expression linked with adult reproductive diapause in a northern malt fly species: a candidate gene microarray study. BMC Ecol. 10, 3

Katzav-Gozansky, T., Soroker, V., Francke, W., Hefetz, A. (2003) Honeybee egg-laying workers mimic a queen signal. Insectes Soc. 50, 20-23
Keeling, C.I., Slessor, K.N., Higo, H.A., Winston, M.L. (2003) New components of the honey bee (Apis mellifera L.) queen retinue pheromone. P. Natl. Acad. Sci.USA 100(8), 4486-4491

Kocher, S.D., Grozinger, C.M. (2011) Cooperation, conflict, and the evolution of queen pheromones. J. Chem. Ecol. 37(11), 1263-1275

Koeniger, N., Koeniger, G. (1980) Observations and experiments on migration and dance communication of Apis dorsata in Sri Lanka. J. Apic. Res. 19, 2134

Kryger, P., Moritz, R.F.A. (1997) Lack of kin recognition in swarming honeybees (Apis mellifera). Behav. Eco. Sociobiol. 40(4), 271-276

Kunert, K., Crailsheim, K. (1988) Seasonal changes in carbohydrate, lipid and protein content in emerging worker honeybees and their mortality. J. Apic. Res. 27, 13-21

Lensky, Y., Slabezki, Y. (1981) The inhibiting effect of the queen bee (Apis mellifera L.) foot-print pheromone on the construction of swarming queen cups. J. Insect Physiol. 27(5), 313-323

Leta, M.A., Gilbert, C., Morse, R.A. (1996) Levels of hemolymph sugars and body glycogen of honeybees (Apis mellifera L.) from colonies preparing to swarm. J. Insect Physiol. 42(3), 239-245

Lewis, L.A., Schneider, S.S. (2000) The modulation of worker behavior by the vibration signal during house hunting in swarms of the honeybee, Apis mellifera. Behav. Ecol. Sociobiol. 48, 154-164

Lewis, L.A., Schneider, S.S. (2008) Migration dances in swarming colonies of the honey bee Apis mellifera. Apidologie 39, 354-361

Li, S.I., Purugganan, M.D. (2011) The cooperative amoeba: Dictyostelium as a model for social evolution. Trends Genet. 27(2), 48-54

Liang, Z.S., Nguyen, T., Mattila, H.R., Rodriguez-Zas, S.L., Seeley, T.D., Robinson, G.E. (2012) Molecular determinants of scouting behavior in honey bees. Science 335, 1225-1228

Lindauer, M. (1955) Schwarmbienen auf Wohnungssuche. Z. vergl. Physiol. 37, 263-324

Ma, Z., Guo, W., Guo, X., Wang, X., Kang, L. (2011) Modulation of behavioral phase changes of the migratory locust by the catecholamine metabolic pathway. Proc. Natl. Acad. Sci. USA 108(10), 3882-3887

MacRae, T.H. (2010) Gene expression, metabolic regulation and stress tolerance during diapause. Cell. Mol. Life Sci. 67, 2405-2424

Makinson, J.C., Oldroyd, B.P., Schaerf, T.M., Wattanachaiyingcharoen, W., Beekman, M. (2011) Moving home: nest-site selection in the Red Dwarf honeybee (Apis florea). Behav. Ecol. Sociobiol. 65(5), 945-958

Martin, P. (1963) Die Steuerung der Volksteilung beim Schwärmen der Bienen. Zugleich ein Beitrag zum 
Problem der Wanderschwärme. Insectes Soc. 10, 13-42

Matsuka, M., Verma, L.R., Wongsiri, S., Shrestha, K.K., Partap, U (eds) (1998) Asian bees and beekeeping: progress of research and development. In: Proceedings of Fourth Asian Apicultural Association International Conference, Kathmandu, 23-28 March 1998. Science Publishers, Inc. Enfield, NH. 274 p

Mattila, H.R., Otis, G.W. (2007) Dwindling pollen resources trigger the transition to broodless populations of long-lived honeybees each autumn. Ecol. Entomol. 32, 496-505

Maurizio, A. (1950) The influence of pollen feeding and brood rearing on the length of life and physiological condition of the honeybee: preliminary report. Bee World 31, 9-12

McGlynn, T.P. (2012) The ecology of nest movement in social insects. Annu. Rev. Entomol. 57, 291-308

McIndoo, N.E. (1915) The scent-producing organ of the honey bee. Proc. Acad. Natl. Sci. Phila. 66, $542-555$

Melathopoulous, A.P., Winston, M.L., Pettis, J.S., Pankiw, T. (1996) Effect of queen mandibular pheromone on initiation and maintenance of queen cells in the honey bee (Apis mellifera L.). Can. Entomol. 128, 263-272

Michelsen, A., Kirchner, W.H., Andersen, B.B., Lindauer, M. (1986) The tooting and quacking vibration signals of honeybee queens: a quantitative analysis. J. Comp. Physiol. A. 158(5), 605-611

Michener, C.D. (2013) The Meliponini. In: Vit, P., Pedro, S.R.M., Roubik, D.W. (eds.) Pot-honey: a legacy of stingless bees, pp. 3-18. Springer, New York

Moneti, G., Dani, F.R., Pieraccini, G., Turillazzi, S. (1997) Solid-phase microextraction of insect epicuticular hydrocarbons for gas chromatographic/mass spectrometric analysis. Rapid Commun. Mass Sp. 11, $857-862$

Morse, R.A. (1963) Swarm orientation in honeybees. Science 141, 357-358

Naumann, K., Winston, M.L., Slessor, K.N. (1993) Movement of honey bee (Apis mellifera L.) queen mandibular pheromone in populous and unpopulous colonies. J. Insect Behav. 6(2), 211-223

Nieh, J.C. (1993) The stop signal of honey bees: reconsidering its message. Behav. Ecol. Sociobiol. 33, 51-56

Nieh, J.C. (1998) The honey bee shaking signal: function and design of a modulatory communication signal. Behav. Ecol. Sociobiol. 42(1), 23-36

Otis, G.W., Winston, M.L., Taylor, O.R. (1981) Engorgement and dispersal of Africanized honeybee swarms. J. Apic. Res. 20(1), 3-11

Ott, S.R., Verlinden, H., Rogers, S.M., Brighton, C.H., Quah, P.S., Vleugels, R.K., Verdonck, R., Vanden Broeck, J. (2012) Proc. Natl. Acad. Sci. USA 109(7), E381-E387
Page, R.E., Peng, C.Y.S. (2001) Aging and development in social insects with emphasis on the honey bee, Apis mellifera L. Exp. Gerontol. 36, 695-711

Page, R.E., Blum, M.S., Fales, H.M. (1988) oAminoaeetophenone, a pheromone that repels honeybees (Apis mellifera L.). Experientia 44(3), 270-271

Page Jr., R.E., Rueppell, O., Amdam, G.V. (2012) Genetics of reproduction and regulation of honeybee (Apis mellifera L.) social behavior. Annu. Rev. Genet. 46, 97-119

Painter-Kurt, S., Schneider, S.S. (1998) Age and behavior of honey bees, Apis mellifera (Hymenoptera: Apidae), that perform vibration signals on queens and queen cells. Ethology 104, 475-485

Peeters, C., Ito, F. (2001) Colony dispersal and the evolution of queen morphology in social Hymenoptera. Annu. Rev. Entomol. 46, 601-630

Pettis, J.S., Higo, H.A., Pankiw, T., Winston, M.L. (1997) Queen rearing suppression in the honey bee-evidence for a fecundity signal. Insectes Soc. 44, 311-322

Pickett, J.A., Williams, I.H., Martin, A.P., Smith, M.C. (1980) Nasonov pheromone of the honey bee, Apis mellifera L. (Hymenoptera: Apidae) Part I. Chemical characterization. J. Chem. Ecol. 6, 425-434

Pierce, A.L., Lewis, L.A., Schneider, S.S. (2007) The use of the vibration signal and working piping behavior during swarming in honey bees, Apis mellifera. Ethology 113(3), 267-275

Queller, D.C. (2008) Behavioural ecology: the social side of wild yeast. Nature 456, 589-590

Rangel, J., Seeley, T.D. (2008) The signals initiating the mass exodus of a honeybee swarm from its nest. Anim. Behav. 76, 1943-1952

Rangel, J., Seeley, T.D. (2012) Colony fissioning in honey bees: size and significance of the swarm fraction. Insectes Soc. 59, 453-462

Rangel, J., Mattila, H.R., Seeley, T.D. (2009) No intracolonial nepotism during colony fissioning in honey bees. Proc. R. Soc. Lond., Biol. Sci. 276, 3895-3900

Rangel, J., Griffin, S.R., Seeley, T.D. (2010) An oligarchy of nest-site scouts triggers a honeybee swarm's departure from the hive. Behav. Ecol. Sociobiol. 64(6), 979-987

Rittschof, C.C., Seeley, T.D. (2008) The buzz-run: how honeybees signal 'Time to go! Anim. Behav. 75, 189-197

Robinson, G.E. (1992) Regulation of division of labor in insect societies. Annu. Rev. Entomol. 37, 637-665

Robinson, G.E., Fernald, R.D., Clayton, D.F. (2008) Genes and social behavior. Science 322(5903), 896-900

Roubik, D.W. (2006) Stingless bee nesting biology. Apidologie 37, 124-143 
Ruttner, F. (1987) Biogeography and taxonomy of honeybees. Springer, New York

Schmidt, J.O. (2001) Hierarchy of attractants for honey bee swarms. J. Insect Behav. 14, 469-477

Schmidt, J.O., Slessor, K.N., Winston, M.L. (1993) Roles of Nasonov and queen pheromones in attraction of honeybee swarms. Naturwissenschaften 80, 573-575

Schmitt, U., Lubke, G., Francke, W. (1991) Tarsal secretion marks food sources in bumblebees (Hymenoptera: Apidae). Chemoecology 2(1), 35-40

Schneider, S.S. (1987) The modulation of worker activity by the vibration dance of the honeybee, Apis mellifera. Ethology 74(3), 211-218

Schneider, S.S. (1990a) Queen behavior and worker queen interactions in absconding and swarming colonies of the African honey bee, Apis mellifera scutellata (Hymenoptera, Apidae). J. Kansas Entomol. Soc. 63(1), 179-186

Schneider, S.S. (1990b) Nest characteristics and recruitment behavior of absconding colonies of the African honey bee, Apis mellifera scutellata, in Africa. J. Insect Behav. 3(2), 225-240

Schneider, S.S. (1991) Modulation of queen activity by the vibration dance in swarming colonies of the African honey bee, Apis mellifera scutellata (Hymenoptera, Apidae). J. Kansas Entomol. Soc. 64(3), 269-278

Schneider, S.S., DeGrandi-Hoffman, G. (2008) Queen replacement in African and European honey bee colonies with and without afterswarms. Insectes Soc. 55(1), 79-85

Schneider, S.S., Lewis, L.A. (2004) The vibration signal, modulatory communication and the organization of labor in honey bees, Apis mellifera. Apidologie 35, 117-131

Schneider, S.S., McNally, L.C. (1991) The vibration dance behavior of queenless workers of the honey bee, Apis mellifera (Hymenoptera: Apidae). J. Insect Behav. 4(3), 319-332

Schneider, S.S., McNally, L.C. (1992) Factors influencing seasonal absconding in colonies of the African honey bee, Apis mellifera scutellata. Insectes Soc. 39(4), 403-423

Schneider, S.S., McNally, L.C. (1994) Waggle dance behavior associated with seasonal absconding in colonies of the African honey bee, Apis mellifera scutellata. Insectes Soc. 41, 115-127

Schneider, S.S., Stamps, J.A., Gary, N.E. (1986) The vibration dance of the honey bee. I Communication regulating foraging on two time scales. Anim. Behav. 34, 377-385

Schneider, S.S., Visscher, P.K., Camazine, S. (1998) Vibration signal behavior of waggle-dancers in swarms of the honey bee, Apis mellifera (Hymenoptera: Apidae). Ethology 104, 963-972
Schneider, S.S., Painter-Kurt, S., DeGrandi-Hoffman, G. (2001) The role of the vibration signal during queen competition in colonies of the honeybee, Apis mellifera. Anim. Behav. 61, 1173-1180

Schultz, K.M., Passino, K.M., Seeley, T.D. (2008) The mechanism of flight guidance in honeybee swarms: subtle guides or streaker bees? J. Exp. Bio. 211, 3287-3295

Seeley, T.D. (1979) Queen substance dispersal by messenger workers in honeybee colonies. Behav. Ecol. Sociobiol. 5, 391-415

Seeley, T.D. (1982) Adaptive significance of the age polyethism schedule in honeybee colonies. Behav. Ecol. Sociobiol. 11, 287-293

Seeley, T.D. (1995) The wisdom of the hive: the social physiology of honey bee colonies. Harvard University Press, Cambridge

Seeley, T.D. (2010) Honeybee democracy. Princeton University Press, Princeton

Seeley, T.D., Buhrman, S.C. (1999) Group decision making in swarms of honey bees. Behav. Ecol. Sociobiol. 45, 19-31

Seeley, T.D., Fell, R.D. (1981) Queen substance production in honey bee (Apis mellifera) colonies preparing to swarm (Hymenoptera: Apidae). J. Kansas Entomol. Soc. 54(1), 192-196

Seeley, T.D., Tautz, J. (2001) Worker piping in honey bee swarms and its role in preparing for liftoff. J. Comp. Physiol. A. 187(8), 667-676

Seeley, T.D., Visscher, P.K. (2004) Group decision making in nest-site selection by honey bees. Apidologie 35(2), 101-116

Seeley, T.D., Morse, R.A., Visscher, P.K. (1979) The natural history of the flight of honey bee swarms. Psyche 86(2-3), 103-114

Seeley, T.D., Weidenmüller, A., Kühnholz, S. (1998) The shaking signal of the honey bee informs workers to prepare for greater activity. Ethology 104, 10-26

Seeley, T.D., Kleinhenz, M., Bujok, B., Tautz, J. (2003) Thorough warm-up before take-off in honey bee swarms. Naturwissenschaften 90(6), 256-260

Seeley, T.D., Visscher, P.K., Passino, K.M. (2006) Group decision making in honey bee swarms. Am. Sci. 94(3), 220-229

Seeley, T.D., Visscher, P.K., Schlegel, T., Hogan, P.M., Franks, N.R., Marshall, J.A.R. (2012) Stop signals provide cross inhibition in collective decisionmaking by honeybee swarms. Science 335(6064), 108-111

Sihag, R.C. (1998) Ecobiology of the little honeybee (Apis florea) in semi-arid subtropical climates of India. In: M. Matsuka, L. R. Verma, S. Wongsiri, K. K. Shrestha and U. Partap (eds) Asian bees and beekeeping: progress of research and development. Science Publishers, Enfield, NY, pp. 50-52 
Simpson, J. (1957a) Observations on colonies of honeybees subjected to treatments designed to induce swarming. Proc. R. Entomol. Soc. London A. 32(10-12), 185-192

Simpson, J. (1957b) The incidence of swarming among colonies of honey-bees in England. J. Agr. Sci. 49, 387-393

Simpson, J. (1958) The factors which cause colonies of Apis mellifera to swarm. Insectes Soc. 5(1), 77-95

Simpson, J. (1959) Variation in the incidence of swarming among colonies of Apis mellifera throughout the summer. Insectes Soc. 6(1), 85-99

Simpson, J. (1963) Queen perception by honeybee swarms. Nature 199, 94-95

Simpson, J., Riedel, I.B.M. (1964) The emergence of swarms from Apis mellifera colonies. Behaviour 23, 140-148

Slessor, K.N., Kaminski, L.-A., King, G.S.S., Borden, J., Winston, M.L. (1988) Semiochemical basis of the retinue response to queen honey bees. Nature 332, 354-356

Slessor, K.N., Winston, M.L., Le Conte, Y. (2005) Pheromone communication in the honeybee (Apis mellifera L.). J. Chem. Ecol. 31(11), 2731-2745

Smith, C.R., Toth, A.L., Suarez, A.V., Robinson, G.E. (2008) Genetic and genomic analyses of the division of labour in insect societies. Nat. Rev. Genet. 9(10), 735-748

Sullivan, J.P., Jassim, O., Fahrback, S.E., Robinson, G.E. (2000) Juvenile hormone paces behavioral development in the adult worker honey bee. Horm. Behav. 37, 1-14

Sumpter, D.J.T. (2006) The principles of collective animal behaviour. Phil. Trans. R. Soc. B 361(1465), 5-22

Tarpy, D.R., Fletcher, D.J.C. (2003) “Spraying” behavior during queen competition in honey bees. J. Insect Behav. 16, 425-437

Toth, A.L., Robinson, G.E. (2005) Worker nutrition and division of labour in honeybees. Anim. Behav. 69, 427-435

Toth, A.L., Robinson, G.E. (2007) Evo-devo and the evolution of social behavior. Trends Genet. 23(7), 334-341

Velicer, G.J., Yu, Y.T. (2003) Evolution of novel cooperative swarming in the bacterium Myxococcus xanthus. Nature 425(6953), 75-78

Venkatesh, G., Reddy, C.C. (1989) Rates of swarming and absconding in the giant honey bee, Apis dorsata F. Proc. Indian Acad. Sci. (Anim. Sci.) 98(6), 425-430

Villella, A., Hall, J.C. (2008) Neurogenetics of courtship and mating in Drosophila. Adv. Genet. 62, 67-187

Visscher, P.K., Seeley, T.D. (2007) Coordinating a group departure: who produces the piping signals on honey bee swarms? Behav. Ecol. Sociobiol. 61, 1615-1621

Visscher, P.K., Shepardson, J., McCart, L., Camazine, S. (1999) Vibration signal modulates the behavior of house-hunting honey bees (Apis mellifera). Ethology 105, 759-769
West-Eberhard, M.J. (1982) The nature and evolution of swarming in tropical social wasps (Vespidae, Polistinae, Polybiini). In: P. Jaisson (ed) Social insects in the tropics, vol. I, pp. 97-128. Univ. Paris XIII Press, Paris

Whitfield, C.W., Behura, S.K., Berlocher, S.H., Clark, A.G., Johnston, J.S., Sheppard, W.S., Smith, D.R., Suarez, A.V., Weaver, D., Tsutsui, N.D. (2006a) Thrice out of Africa: ancient and recent expansions of the honey bee, Apis mellifera. Science 314, 642-645

Whitfield, C.W., Ben-Shahar, Y., Brillet, C., Leoncini, I., Crauser, D., Le Conte, Y., Rodriguez-Zas, S., Robinson, G.E. (2006b) Genomic dissection of behavioral maturation in the honey bee. Proc. Natl. Acad. Sci. USA 103(44), 16068-16075

Wilson, E.O. (1971) The insect societies. Harvard University Press, Cambridge

Winston, M.L. (1979) Intra-colony demography and reproductive rate of the Africanized honeybee in South America. Behav. Ecol. Sociobiol. 4, 279-292

Winston, M.L. (1980) Swarming, afterswarming, and reproductive rate of unmanaged honeybee colonies (Apis mellifera). Insectes Soc. 27(4), 391-398

Winston, M.L. (1987) The biology of the honey bee. Harvard University Press, Cambridge

Winston, M.L., Taylor, O.R. (1980) Factors preceding queen rearing in the Africanized honeybee (Apis mellifera) in South America. Insectes Soc. 27(4), 289-304

Winston, M.L., Dropkin, J.A., Taylor, O.R. (1981) Demography and life history characteristics of two honey bee races (Apis mellifera). Oecologia 48(3), 407-413

Winston, M.L., Slessor, K.N., Smirle, M.J., Kandil, A.A. (1982) The influence of a queen-produced substance, 9HDA, on swarm clustering behavior in the honeybee Apis mellifera L. J. Chem. Ecol. 8(10), 1283-1288

Winston, M.L., Slessor, K.N., Willis, L.G., Naumann, K., Higo, H.A., Wyborn, M.H., Kaminski, L.A. (1989) The influence of queen mandibular pheromones on worker attraction to swarm clusters and inhibition of queen rearing in the honey bee (Apis mellifera L.). Insectes Soc. 36(1), 15-27

Winston, M.L., Higo, H.A., Colley, S.J., Pankiw, T., Slessor, K.N. (1991) The role of queen mandibular pheromone and colony congestion in honey bee (Apis mellifera L.) reproductive swarming (Hymenoptera: Apidae). J. Insect Behav. 4(5), 649-660

Wossler, T.C., Crewe, R.M. (1999a) Honeybee queen tergal gland secretion affects ovarian development in caged workers. Apidologie 30, 311-320

Wossler, T.C., Crewe, R.M. (1999b) The releaser effects of the tergal gland secretion of queen honeybees (Apis mellifera L.). J. Insect Behav. 12, 343-350

Zeng, Z., Huang, Z.H., Qin, Y., Pang, H. (2005) Hemolymph juvenile hormone titers in worker honey bees under normal and preswarming conditions. J. Econ. Entomol. 98(2), 274-278 